Atsuki Fukushima

Hisayuki Ueno

\section{The relationship between HTLV-I-infected cell lines and uveitis}

Received: 25 August 1993

Revised version received: 22 February

Accepted: 1 September 1994
A. Fukushima $(\bowtie) \cdot H$. Ueno

Department of Ophthalmology, Kochi

Medical School, Kohasu, Oko-cho,

Nankoku 783, Japan

Tel./Fax: + 81-888662194

\begin{abstract}
Background: Recently it has been revealed that human Tlymphotropic virus type I (HTLVI) infection causes uveitis in human. We previously reported HTLV-I uveitis in a rabbit. To investigate the relationship between HTLV-I infection and uveitis, we established an HTLV-I-infected Tcell clone from the cells infiltrated in the anterior chamber of this rabbit and compared the viral production with that in other HTLV-I-infected cell lines. Methods: The clonality was determined by Southern blot hybridization with various restriction enzymes. Flow-cytometric analysis was used for investigating the expression of cell surface antigens. To compare viral production, we performed reverse tran-
\end{abstract}

scriptase assay of the culture media and inhibition enzyme-linked immunosorbent assay to determine the quantity of intracellular HTLV-I antigens. Results: The established clone was Ia (MHC class II) positive $\mathrm{T}$ cell. This T-cell clone was able to produce about three times more HTLV-I antigens than other HTLV-I-infected cell lines tested. Conclusion: A Tcell clone established from anterior aqueous of an HTLV-I uveitis rabbit can produce more HTLV-1 antigen than other HTLV-I-infected cell lines tested and it can be recognized easily by the immune system. Therefore, this high virus production may have a causal relation to uveitis.

\section{Introduction}

Human T-lymphotropic virus type I (HTLV-I) is thought to be the causative agent not only of adult Tcell leukemia (ATL) [1] but also of HTLV-I-associated myelopathy (HAM/TSP) [2], HTLV-I-associated arthropathy (HAAP) [3], and HTLV-I uveitis [4]. Several studies have revealed that HTLV-I causes immunologic abnormalities in vitro [5-8]. Based on these findings, HTLV-I-associated syndrome, which includes these immune-mediated diseases, has been proposed. There are several reports of experimental models of the HTLV-I-associated syndrome $[9,10]$, and we previously have reported HTLV-I uveitis in a rabbit [11]. There have been no reports of the establishment of an HTLV-
I-infected T-cell line or clone from anterior chamber infiltrating cells of HTLV-I uveitis patients. We established a T-cell clone from the cells in the anterior aqueous chamber of the eye for the first time, and a T-cell line from the peripheral blood lymphocytes of this rabbit. We also found the existence of antigenic crossreactivity between HTLV-I and retinal antigens recognized by T cells [12], and we postulated that as HTLV-Iinfected cells have more HTLV-I antigens, the immune system can recognize and respond to HTLV-I-infected cells and these responses lead to the expansion of autoreactive $T$ cells against retina and to uveitis. Therefore, in an effort to ascertain the relationship between HTLV-I-infected cell lines and uveitis, we examined viral production in these cell lines. 


\section{Materials and methods}

HTLV-I uveitis model

One rabbit developed bilateral uveitis 3.5 years after transfusion of $10 \mathrm{ml}$ peripheral blood from an HTLV-I-infected rabbit [11]. Uveitis was diagnosed by histopathologic examination.

\section{Cell lines}

Two HTLV-I-infected cell lines were established. One, from the peripheral blood, was named UV-2, while the other, from the anterior chamber of the eye, was named UV-1. They were generated by co-cultivation with normal rabbit peripheral blood lymphocytes which were attenuated by irradiation (10000 rad). Other HTLV-I-infected cell lines included the human T-cell line MT-2 [13], the rabbit T cell line Ra-1 [14], Melanesian ATL [15], and the peripheral blood lymphocytes of an HTLV-I carrier patient (MN). All cell lines were cultured in RPMI 1640 medium supplemented with $10 \%$ heat-inactivated fetal calf serum (FCS; ICN Biomedicals Japan, Osaka) and $5 \times 10^{-5} \mathrm{M} 2$-mercaptoethanol (2-ME) in the presence of $50 \mathrm{IU} / \mathrm{ml}$ interleukin-2 (IL-2) (Takeda, Osaka).

\section{Generation of RAC-1 as the T-cell clone of UV-1}

T-cell cloning was accomplished by limiting dilution [16]. Briefly, UV-1 cells were plated at a density of 0.3 cells/well and cultured on a 96-well flat-bottomed microplate (Nunc, Roskilde, Denmark) in $200 \mu \mathrm{l}$ of RPMI 1640 containing $10 \% \mathrm{FCS}, 5 \times 10^{-5} \mathrm{M} 2-\mathrm{ME}$, and $50 \mathrm{IU} / \mathrm{ml} \mathrm{IL-2.} \mathrm{Two} \mathrm{weeks} \mathrm{later,} \mathrm{two} \mathrm{T-cell} \mathrm{sublines} \mathrm{were}$ established. The same manipulation was repeated, and one clone was established and designated RAC-1.

\section{Detection of proviral DNA integrated in cellular DNA}

More than $10^{7} \mathrm{RAC}-1$ cells, MT-2 cells, and MN cells were used to prepare cellular DNA. High-molecular-weight DNA was extracted by treating the cells overnight with sodium dodecyl sulfate/proteinase $K$, followed by phenol extraction. Then cellular DNA was digested with EcoRI or PstI and the digest was separated by electrophoresis in an agarose gel. The DNAs in the gel were blotted onto a nitrocellulose filter and hybridized with cloned viral DNAs (lambda-HTLV-I) using standard conditions. The filter was washed several times at $65^{\circ} \mathrm{C}$ and then was exposed to $\mathrm{X}$-ray film at $-70^{\circ} \mathrm{C}$.

\section{Cell surface markers and viral antigens}

A monoclonal antibody to rabbit T cells (L11/135) [17] and rabbit Ia (MHC class II) antigen (2C4) [18] were used for the flow-cytometric analysis. HTLV-I antigens were examined by fixed-cell indirect immunofluorescence using a reference serum from a patient with ATL and monoclonal antibodies to HTLV-I p19 and p24 [19].

\section{Flow-cytometric analysis}

RAC-1 cells were incubated with the appropriate dilutions of the first antibodies (anti-rabbit $\mathrm{T}$ cell and anti-rabbit Ia) for $30 \mathrm{~min}$ on ice and washed once with PBS containing $1 \%$ FCS. The cells were incubated further with FITC-conjugated second antibody for $30 \mathrm{~min}$ on ice. The cells were washed once, and flow-cytometric analysis was performed in an EPICS 752 (Coulter Electronics, Hialeah, Fla.).

\section{Reverse transcriptase assay}

The number of released virus particles was estimated by the detection of reverse transcriptase (RNA-dependent DNA polymerase) activity in each cultured cell medium [20]. A quantity of $12 \mathrm{ml}$ of each culture medium, harvested when the cells reached a concentration of $1 \times 10^{6}$ cells $/ \mathrm{ml}$, was centrifugated at $7200 \mathrm{~g}$ for $10 \mathrm{~min}$ and the supernatant was then centrifugated at $120000 \mathrm{~g}$ for $3 \mathrm{~h}$ at $4^{\circ} \mathrm{C}$. The pellet was resuspended in $50 \mu \mathrm{l}$ of $50 \mathrm{mM}$ Tris- $\mathrm{HCl}$ ( $\mathrm{pH}$ 7.8). Reverse transcriptase activity in $25 \mu \mathrm{l}$ of the virus suspension was assayed in a standard reaction mixture $(100 \mu \mathrm{l}) \mathrm{con}-$ taining $50 \mathrm{mM}$ Tris- $\mathrm{HCl}(\mathrm{pH} 7.8), 60 \mathrm{mM} \mathrm{KCl}, 0.05 \mathrm{mM} \mathrm{MnCl}$, $2 \mathrm{mM}$ dithiothreitol, $0.05 \%$ Triton X-100, 0.4 A260 unit poly(A) oligo(dT), and $5 \mu \mathrm{Ci}$ of ${ }^{3} \mathrm{H}$-labeled 2 -deoxythymidine 5 '-triphosphate (TTP; Amersham, Tokyo, Japan; $116 \mathrm{Ci} / \mathrm{mmol}$ ) followed by $1 \mathrm{~h}$ incubation at $37^{\circ} \mathrm{C}$. The acid precipitable counts were measured using a liquid scintillation analyzer.

\section{Quantification of intracellular HTLV-I antigens}

Cell pellets were made as above. Their cell membranes were destroyed by $0.2 \%$ deoxycholic acid sodium, and then supercentrifugated (30000 rpm, 90 minutes). After centrifugation, the supernatants were collected and named "HTLV-I antigen fluid". The amount of HTLV-I antigen in this fluid was measured by the antigen competition method using a commercially available enzyme-linked immunosorbent assay kit (Eitest-ATL, EISAI, Tokyo).

\section{Results}

Southern blot analysis

The cellular DNA samples were digested with EcoRI, which does not cut the HTLV-I proviral genome. In this

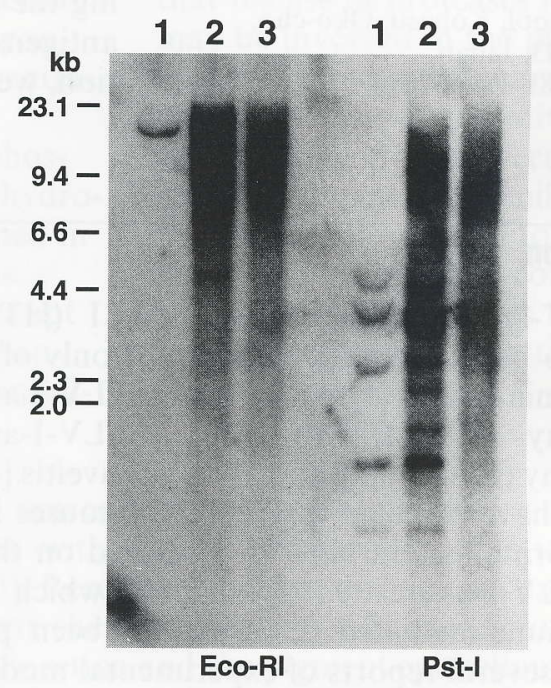

Fig. 1 Southern blot analysis of RAC-1. A discrete band was detected in RAC-1 (lane 1), and multiple bands were seen in MT-2 (lane 2) and MN (lane 3) 


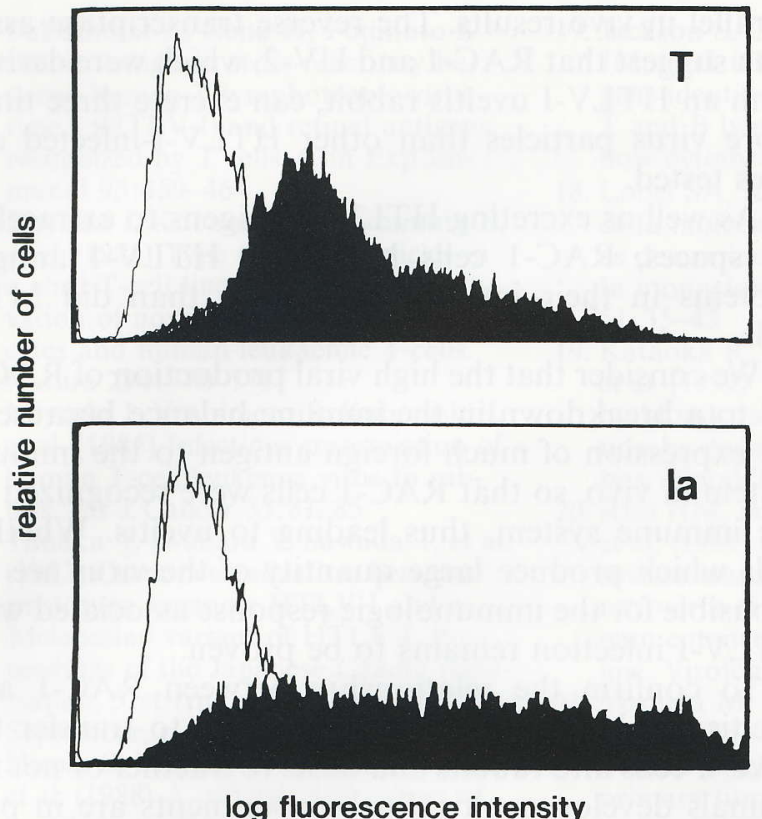

Fig. 2 Flow-cytometric analysis of RAC-1. More than half of RAC-1 cells were positive for anti-T-cell marker (L11/135) and anti-Ia marker (2C4)

assay, any provirus DNA sequence which integrated at a single chromosomal location was detected as a discrete band, but sequences which integrated into multiple sites would yield multiple bands [21]. As shown in Fig. 1, the HTLV-I proviral genome inserted in RAC-1 at only one site, whereas in MT-2 and MN it had many insertion sites.

Flow-cytometric analysis

More than half of RAC- 1 cells were positive for anti-Tcell marker and anti-Ia (Fig. 2).

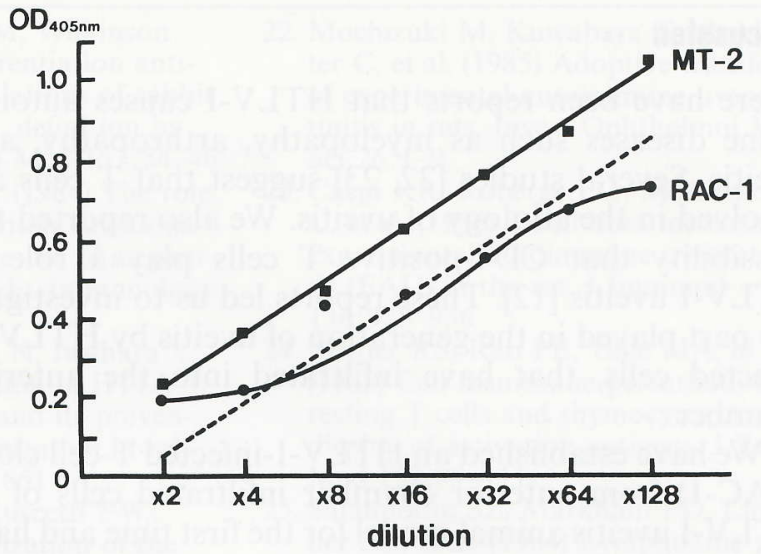

Fig. 4 Quantification of intracellular HTLV-I antigens. RAC-1 cells had about three times more HTLV-I antigens than did MT-2 cells. Dotted line parallel line of inclination of RAC-1 cells to MT-2

Reverse transcriptase assay

As shown in Fig. 3, in experiments 1 and 2 the incorporation of $\left[{ }^{3} \mathrm{H}\right]-\mathrm{TTP}$ in RAC-1 and UV-2 cells was about three times greater than in the other HTLV-I infected cell lines tested.

\section{Quantification of intracellular HTLV-I antigens}

In order for the HTLV-I antigen fluid of MT-2 and RAC-1 to yield an equivalent absorbance (at $405 \mathrm{~nm}$ ), the HTLV-I antigen fluid of RAC-1 had to be diluted threefold more, implying that RAC-1 cells had about three times more HTLV-I protein antigen than did MT2 (Fig. 4).
Fig. 3 Reverse transcriptase assay of HTLV-I-infected cell lines. $\left[{ }^{3} \mathrm{H}\right]$-TTP incorporation in the supernatants of RAC-1 and UV-2 cells was about three times greater than in those of the other HTLV-I-infected cell lines

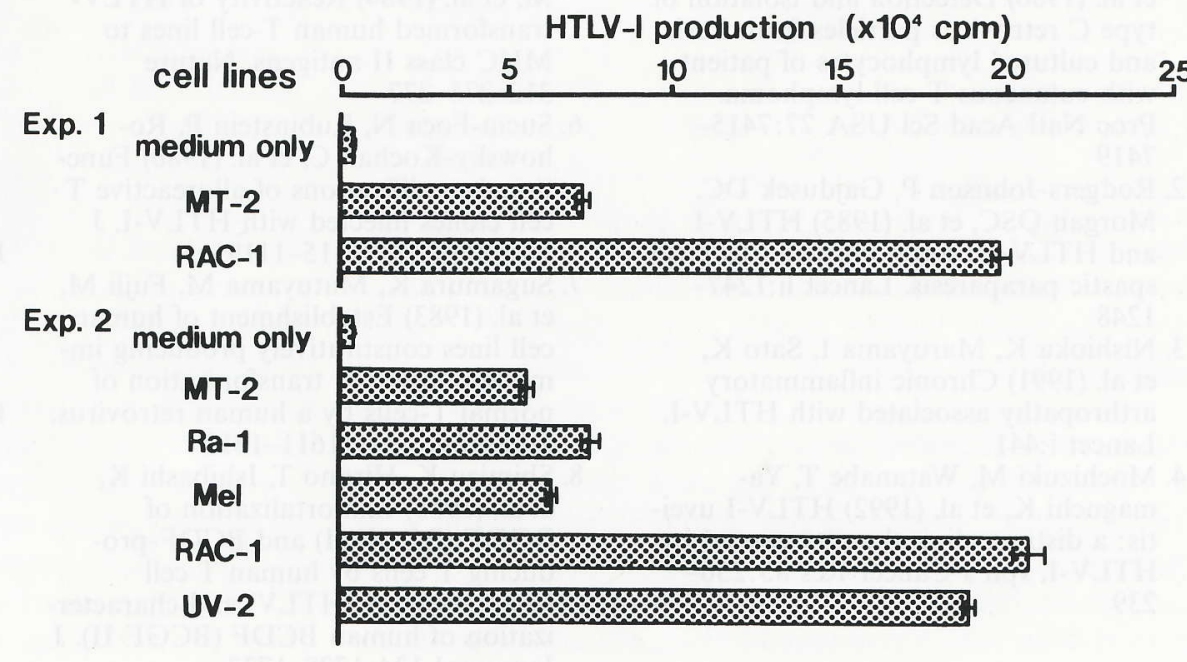




\section{Discussion}

There have been reports that HTLV-I causes autoimmune diseases such as myelopathy, arthropathy, and uveitis. Several studies $[22,23]$ suggest that $T$ cells are involved in the etiology of uveitis. We also reported the possibility that CD4-positive $\mathrm{T}$ cells play a role in HTLV-I uveitis [12]. These reports led us to investigate the part played in the generation of uveitis by HTLV-Iinfected cells, that have infiltrated into the anterior chamber.

We have established an HTLV-I-infected T-cell clone (RAC-1) from anterior chamber infiltrated cells of an HTLV-I uveitis animal model for the first time and have characterized it. This T-cell clone can produce HTLV-I viruses as demonstrated by reverse transcriptase assay and quantification of intracellular virus antigen. This clone was able to produce greater quantities of HTLV-I virus than any other HTLV-I-infected cell lines tested.

Ia (MHC class II) molecules are thought to be surface markers for activated T cells [24], and RAC-1 cells had Ia molecules on their surface. This suggests that they were activated. In inflammatory diseases, especially those thought to be caused by immunologic agents, the proportion of Ia-positive $T$ cells in peripheral blood lymphocytes increases [24]. Even though HTLV-I-infected cells were generally Ia positive, and Ia positivity is not unique to RAC-1, there may be some relationship between RAC-1 and the generation of uveitis in this model.

For the reverse transcriptase assay, virus particles in the culture medium were used, so that we only evaluated the quantity of secreted HTLV-1 virus particles from cells. Furthermore, these types of assays do not always parallel in vivo results. The reverse transcriptase assay data suggest that RAC-1 and UV-2, which were derived from an HTLV-I uveitis rabbit, can excrete three times more virus particles than other HTLV-I-infected cell lines tested.

As well as excreting HTLV-I antigens to extracellular spaces, RAC-1 cells had more HTLV-1 antigen proteins in their intracellular spaces than did MT-2 cells.

We consider that the high viral production of RAC-1 led to a breakdown in the immune balance because of the expression of much foreign antigen to the immune system in vivo, so that RAC-1 cells were recognized by the immune system, thus leading to uveitis. Whether cells which produce large quantity of the virus are responsible for the immunologic response associated with HTLV-I infection remains to be proven.

To confirm the relationship between RAC-1 and uveitis, we believe that it is important to transfer the RAC- 1 cells into rabbits and observe whether or not the animals develop uveitis. Such experiments are in progress.

Another important area of research is the level of cytokine synthesis by these cell lines [25], because there may be a direct relationship between such cytokine synthesis and uveitis. Cytokines such as interleukin-1 and tumor necrosis factor can augment inflammation and damage tissues directly. Experiments which should help clarify the mechanism of uveitis in this animal model are also underway.

Acknowledgements We would like to thank Dr. I. Miyoshi for critical reading of the manuscript, Dr. H. Taguchi and Dr. S Fujimoto for discussions, and Dr. M. Hatanaka for providing lambda-HTLV-I.

\section{References}

1. Poiesz BJ, Ruscetti FW, Gazdar AF, et al. (1980) Detection and isolation of type $\mathrm{C}$ retrovirus particles from fresh and cultured lymphocytes of patient with cutaneous T-cell lymphoma. Proc Natl Acad Sci USA 77:74157419

2. Rodgers-Johnson P, Gajdusek DC, Morgan OSC, et al. (1985) HTLV-I and HTLV-III antibodies and tropical spastic paraparesis. Lancet ii:12471248

3. Nishioka K, Maruyama I, Sato K, et al. (1991) Chronic inflammatory arthropathy associated with HTLV-I Lancet $i: 441$

4. Mochizuki M, Watanabe T, Yamaguchi K, et al. (1992) HTLV-I uveitis: a distinct clinical entity caused by HTLV-I. Jpn J Cancer Res 83:236239
5. Suciu-Foca N, Rubinstein P, Popovic M, et al. (1984) Reactivity of HTLVtransformed human T-cell lines to MHC class II antigens. Nature 312:275-277

6. Suciu-Foca N, Rubinstein P, Rohowsky-Kochan C, et al. (1986) Functional modifications of alloreactive $\mathrm{T}$ cell clones infected with HTLV-I. J Immunol 137:1115-1119

7. Sugamura K, Matuyama M, Fujii M, et al. (1983) Establishment of human cell lines constitutively producing immune interferon: transformation of normal T-cells by a human retrovirus. J Immunol 131:1611-1612

8. Shimizu K, Hirano T, Ishibashi K, et al. (1985) Immortalization of BGDF (BCGF II) and BCDF-producing $T$ cells by human $T$ cell leukemia virus (HTLV) and characterization of human BCDF (BCGF II). J Immunol 134:1728-1733
9. Ishiguro N, Abe N, Seto K, et al. (1992) A rat model of human T lymphocyte virus type I (HTLV-I) infection. 1. Humoral antibody response, provirus integration, and HTLV-I-associated myelopathy/tropical spastic paraparesis-like myelopathy in seronegative HTLV-I carrier rats. J Exp Med 176:981-989

10. Iwakura T, Tosu M, Yoshida E, et al. (1991) Induction of inflammatory arthropathy resembling rheumatoid arthritis in mice transgenic for HTLV-I. Science 253:1026-1028

11. Taguchi H, Sawada T, Fukushima A et al. (1993) Bilateral uveitis in a rabbit experimentally infected with human T lymphotropic virus type I. Lab Invest 69:336-339 
12. Fukushima A, Ueno H, Fujimoto $S$ (1994) Antigenic cross-reactivity between human $\mathrm{T}$ lymphotropic virus type I (HTLV-I) and retinal antigens recognized by T cells. Clin Exp Immunol 95:459-464

13. Miyoshi I, Kubonishi I, Yoshimoto S, et al. (1981) Type C virus particles in a cord $\mathrm{T}$-cell line derived by co-cultivation of normal human cord leukocytes and human leukaemic T-cells. Nature 294:770-771

14. Miyoshi I, Yoshimoto S, Kubonishi I, et al. (1985) Infectious transmission of human T-cell leukemia virus to rabbits. Int J Cancer 35:81-85

15. Tanaka Y, Iwahara Y, Sawada T, et al. (1992) Cross-neutralization between prototype Japanese HTLV-I and a Melanesian variant of HTLV-I. Proceedings of the Japanese Cancer Association, 51st Annual Meeting, Osaka, September, p 79

16. Hirose S, McAllister CG, Mittal KK, et al. (1988) A cell line and clones of lymphocytes from a healthy donor, with specificity to S-antigen. Invest Ophthalmol Vis Sci 29:1636-1641
17. Jackson S, Chused TM, Wilkinson JM, et al. (1983) Differentiation antigens identify subpopulations of rabbit $\mathrm{T}$ and $\mathrm{B}$ lymphocytes: definition by flow cytometry. J Exp Med 157:34-46

18. Lobel SA, Knight KL (1984) The role of Ia molecules in immune functions as determined with the use of an antiIa monoclonal antibody. Immunology 51:35-43

19. Kataoka R, Takehara N, Iwahara Y, et al. (1991) Transmission of HTLV-I by blood transfusion and its prevention by passive immunization in rabbits. Blood 76:1657-1661

20. Rho HM, Poiesz B, Ruscetti FW, et al. (1981) Characterization of the reverse transcriptase from a new retrovirus (HTLV) produced by a human cutaneous T-cell lymphoma cell line. Virology 112:355-360

21. Yoshida M, Seiki M, Yamaguchi K, et al. (1984) Monoclonal integration of human T-cell leukemia provirus in all primary tumors of adult T-cell leukemia suggests causative role of human T-cell leukemia virus in the disease. Proc Natl Acad Sci USA 81:2534-2537
22. Mochizuki M, Kuwabara T, McAllister C, et al. (1985) Adoptive transfer of experimental autoimmune uveoretinitis in rats. Invest Ophthalmol Vis Sci 26:1-9

23. Caspi RR, Roberge FG, McAllister C, et al. (1986) T cell lines mediating experimental autoimmune uveoretinitis (EAU) in the rat. J Immunol 136:928-936

24. Mittler RS, Rao PE, Talle MA, et al. (1983) Cell membrane perturbation of resting $T$ cells and thymocytes causes display of activation antigens. J Exp Med 158:99-111

25. Salahuddin SZ, Markham PD, Lindner SG, et al. (1984) Lymphokine production by cultured human T cells transformed by human T-cell leukemia-lymphoma virus type I. Science 223:703-707 